\title{
Systematiske litteratursøk til salgs: Ny tjeneste fra biblioteket
}

\author{
Best practice article
}

\section{Malene Wøhlk Gundersen, Tordis Korvald, Inga Lena Grønlund*, Elisabeth Karlsen, Anne Tangen, Camilla Thorvik, Ingjerd Legreid Ødemark.}

Universitetsbiblioteket, OsloMet - storbyuniversitetet (tidligere Laeringssenter og bibliotek, Høgskolen i Oslo og Akershus).

\begin{abstract}
The popularity of the review article as a publication type has increased dramatically during the last decades. As the number of single studies published each year has reached staggering heights, the need to summarize or synthesize these has proportionally increased. As one of their core services libraries throughout Norway provides access for their users to as much of the published research as possible. Unfortunately, that is not equivalent to enabling the users to locate relevant research. This is a challenge often requiring a special skill set and expertise in literature searching, both which is often found among specialized librarians. Requests from researchers at OsloMet - Oslo Metropolitan University (formerly Oslo and Akershus University College of Applied Sciences) for assistance from the librarians in performing systematic literature searches was the basis in developing the literature search service described in this article. How a typical request for a literature search is handled, what the product comprises and which aspects that will be prioritized in the future is expounded. Furthermore, the authors describe some of the experiences in launching this service as a service charging the researchers for librarian assistance on an hourly basis. Finally, challenges and unresolved issues are commented on.
\end{abstract}

Keywords: library, research services, systemtatic reviews, payment services, bibliotek, forskningsstøtte, systematiske søk, betalingstjeneste

\footnotetext{
*Contact:

Inga Lena Grønlund

e-mail:ingro@oslomet.no
} 


\section{Innledning}

Ulike typer litteraturgjennomganger $\varnothing$ ker i antall og popularitet. Systematiske oversikter hvor en sammenstiller forskningsresultater fra studier om en gitt problemstilling, nødvendiggjør en mer systematisk tilnærming til det å innhente tidligere publisert forskning (Nasjonalt kunnskapssenter for helsetjenesten, 2015). Innenfor helsefagene er det tradisjon for å bruke profesjonell bistand ved gjennomføring av systematiske litteraturs $\varnothing \mathrm{k}$. I hvilken grad en oversikt er systematisk eller ikke, vil blant annet avgjøres av metodikken i litteraturs $\varnothing$ ket. Tranfield, Denyer og Smart (2003) hevder at det som særmerker systematiske litteratursøk er «a replicable, scientific and transparent process, in other words a detailed technology, that aims to minimize bias through exhaustive literature searches of published and unpublished studies and by providing an audit trail of the reviewers decisions, procedures and conclusions.» (Tranfield et al., 2003, s. 209).

Slike søk etterspørres i større grad også innenfor andre felt enn helsefagene, og da særlig innenfor samfunnsvitenskapene. Utviklingen har også gjort seg gjeldende ved OsloMet. Om lag $40 \%$ av oppdragene til ressursgruppen så langt er utpreget helsefaglige og kommer fra fakultet for helsefag. De resterende $60 \%$ kommer fra andre fagmiljø ved organisasjonen, og spenner over emner som integrering, arbeidsmarkedsproblematikk, diskriminering, flyktninger og evaluering av nasjonale varslingstjenester.

I denne artikkelen vil vi redegjøre for bakgrunnen for opprettelsen av Ressursgruppen for litteraturs $\emptyset \mathrm{k}$ ved OsloMet, heretter ressursgruppen, og arbeidet gruppen har utført så langt. Fokus er på utvikling av metoder, rutiner og leveranser samt kompetanseutvikling. Betaling for tjenesten og ressursbruk er gjenstand for problematisering og diskusjon, samtidig som vi tillater oss å løfte blikket og se framover.

\section{Bakgrunn}

I 2015 fikk biblioteket et større oppdrag fra en av forskningsinstitusjonene ved Senter for velferds- og arbeidslivsforskning (SVA) på OsloMet. Senteret var nylig etablert som et ledd i den daværende høyskolens universitetssatsing. Erfaringen fra dette oppdraget viste at biblioteket ikke var rigget for å håndtere slike oppdrag i tillegg til ordinær drift og andre oppgaver med tilhørende tidsfrister.

Ett av hovedmålene i OsloMets strategi frem mot 2024 er at storbyuniversitetet skal være en ledende leverandør av forskningsbasert kunnskap for velferdssamfunnet (Høgskolen i Oslo og Akershus, 2017). I tråd med dette ønsket biblioteket å utvikle en systematisk og helhetlig tilnærming til henvendelser fra forskere med behov for bistand til eller leveranser av systematiske litteraturs $\varnothing \mathrm{k}$. Det ble derfor nedsatt en arbeidsgruppe med et bredt mandat knyttet til bibliotekets tilbud innenfor forskerstøtte. Arbeidsgruppen avgrenset arbeidet til å utvikle et tilbud med systematiske litteraturs $\varnothing \mathrm{k}$, og ressursgruppen ble opprettet. Tjenesten som leveres er ment å være et tillegg til de eksisterende tjenestene biblioteket tilbyr.

Spesiell kompetanse er nødvendig for å gjenfinne relevant forskning på tvers av tilgjengelige ressurser. Gjennom dette antar vi at digitale ressurser som databaser, tidsskrifter og samlingen for $\emptyset$ vrig vil bli mer og bedre utnyttet, samtidig som bibliotekarenes kompetanse vil bli mer synlig og tilgjengelig. At bibliotekene kjøper inn tilganger til flere titalls databaser og flere tusen elektroniske tidsskrifter er ikke ensbetydende med at forskerne klarer å nyttiggjøre seg av det fulle potensialet disse tilgangene gir. 


\section{Beskrivelse av tjenesten}

Ressursgruppen har en bred akademisk bakgrunn som omfatter bibliotekfag, helsefag, humaniora og ulike samfunnsvitenskapelige disipliner. Medlemmene er knyttet til ulike fagmiljøer ved OsloMet, og representerer per i dag alle bibliotekene ved universitetet.

Da ressursgruppen utviklet tjenesten var målet et enhetlig tilbud med tilhørende rutiner rettet mot forskere og faglig ansatte. Vi tok utgangspunkt i etablerte søkemetoder fra helsefagene. Dette var et bevisst valg, både fordi metodene er utprøvde og fordi flere medlemmer i ressursgruppen har bred erfaring fra litteratursøk innenfor disse fagene. Informasjonen om den ferdig utviklede tjenesten ble lagt ut på bibliotekets nettside. Brev om tjenesten ble også sendt ut til nøkkelpersoner ved alle fakultet og forskermiljø, som forskningsledere og økonomisjefer. I tillegg presenterte flere av oss tilbudet $\mathrm{i}$ aktuelle fora for ansatte.

Bibliotekets nettside informerer om hva ressursgruppen kan tilby og gir en eksplisitt orientering om hva oppdragsgiver forventes å bidra med. I tillegg presenteres det hva en standard leveranse fra ressursgruppen kan bestå av:

- Beskrivelse av utviklingen i søket.

- Dokumentasjon som også kan inkorporeres som metodetekst i oppdragsgivers egen tekst.

- Søkehistorikk.

- Treffliste $\mathrm{i}$ et EndNote-bibliotek, Word-fil eller liknende, samt påbegynt PRISMAdiagram (flytdiagram som viser trinnene i søkeprosessen (Moher, Liberati, Tetzlaff \& Altman, 2009)).

- Fagfellevurdering (kvalitetssikring av søket).

Det enkelte oppdragets omfang og hensikt avgjør hvilke av disse elementene vi leverer.

Et oppdrag starter typisk med at en forsker tar kontakt med ressursgruppen og ber om hjelp til et litteratursøk. Dette skjer enten ved at forskeren tar personlig kontakt, eller sender en henvendelse til ressursgruppens e-post, litteratursok@hioa.no. Hvis det viser seg å være et tidkrevende oppdrag, legges det frem for resten av ressursgruppen for å få en rask avklaring på om vi har kapasitet til å ta oppdraget og hvem som kan ta det. Deretter ber vi om et snarlig oppstartsmøte med oppdragsgiver. Her ønsker vi så langt som mulig å avklare elementer som omfang av søket, tematikk, tidsfrister, inkludering- og ekskluderingskriterier, valg av databaser og å identifisere relevant fagterminologi. Neste trinn er å utføre testsøk basert på den informasjonen vi har fått. Oppdragsgiver må så vurdere resultatet og gi tilbakemelding på om vi er på rett spor.

Når den endelige søkestrategien er bestemt og godkjent av oppdragsgiver kvalitetssikres litteratursøket gjennom fagfellevurdering. Fagfellevurderingen utføres av en annen bibliotekar i ressursgruppen etter en standardisert mal, men vil, avhengig av oppdragenes karakter, ha varierende omfang. Fagfellevurdering har vist seg å være både nyttig og nødvendig for et vellykket og mer konsistent litteratursøk.

\section{Et halvt år med erfaring}

Etter lanseringen november 2016 frem til september 2017 har ressursgruppen mottatt og effektuert 11 litteraturs $\varnothing \mathrm{k}$, med flere som venter i kø utover høsten 2017. Så langt er erfaringen 
at de fleste av oppdragene er fra helsefag og samfunnsfagene. Noen prosjekter har ekstern finansiering, mens andre er basert på egenfinansiering.

Til nå har ressursgruppens medlemmer stort sett jobbet i par på tvers av fagområder for å integrere kompetanseheving $\mathrm{i}$ gjennomføringen av oppdragene. Sannsynligvis vil medlemmene etter hvert oftere jobbe enkeltvis i takt med at rutinene kommer på plass og erfaringen med litteraturs $\varnothing \mathrm{k} \emptyset \mathrm{ker}$. Når oppdrag kommer fra faggrupper tilknyttet andre kontaktbibliotekarer enn de som deltar i ressursgruppen, er det nærliggende at disse blir involvert i søket. Slik får kontaktbibliotekarer også utenfor ressursgruppen bredere erfaring med søk, og ressursgruppen drar veksler på deres kompetanse i et gitt fagområde. Det er et uttalt mål å spre kompetansen.

Noen av henvendelsene vi får medfører kun veiledning i litteraturs $\varnothing \mathrm{k}$, eller begrensede søk for oppdragsgiver. Vi har satt en grense på 5 timer før vi vurderer internfakturering. Slike mindre oppdrag vurderer vi også om vi kan henvise videre til kolleger som er kontaktbibliotekarer på det aktuelle fagfeltet, og vi anser dette som innenfor vårt ordinære bibliotektilbud.

\section{Gratisprinsippet}

Tradisjonelt har biblioteksektoren i Norge frontet at kunnskap og informasjon skal gjøres tilgjengelig og formidles gratis til bibliotekenes brukere. Innenfor dette kan gratisprinsippet forstås som et viktig verktøy for å sikre en demokratisk tilgang til velferdsgodene. Hos noen norske bibliotek selges utvalgte tjenester til de som regnes som eksterne brukere, men man tar i mindre grad betaling for bibliotektjenester fra egne brukere.

Forskere ved OsloMet søker jevnlig Norges forskningsråd og EU om midler til å finansiere forskningen sin. Ved etableringen av tjenesten ble det antatt at det var forskere som mottok ekstern finansiering som i hovedsak ville benytte seg av tjenesten. Ressursgruppen har en timepris på 412 kroner, som er om lag 150 kroner under gjennomsnittet for tilsvarende tjenester ved internasjonale institusjoner det er naturlig å sammenligne seg med. Sammenligner man timeprisen som legges til grunn ved prissetting av forskningstid, er tjenesten fra OsloMet svært konkurransedyktig. Dette gjør tilbudet om litteratursøk attraktivt for forskere, også $\emptyset$ konomisk.

Betalingsaspektet vil også fungere som en synliggjøring av bibliotekarens kompetanse. Ved å ta betaling for tjenesten, sendes et signal om at oppgaven er både tids- og kompetansekrevende, og at det er en oppgave ikke alle er i stand til å utføre. Dette kan føre til en bevisstgjøring hos forskeren knyttet til bibliotekarens rolle i en forskningsprosess. Vi antar at tjenesten spesielt appellerer til forskere som har et bevisst forhold til litteratursøk som et sentralt element i deres forskning. Ved å tilby en spesialisert betalingstjeneste antar vi også at risikoen for tidstyveri i form av lite relevante eller unødvendige søkeoppdrag kan reduseres. Det er også rimelig å anta at en tjeneste som krever betaling vil heve bestillingskompetansen hos forskerne.

Det er også et håp at informasjon om denne tjenesten vil medføre at forskerne tar kontakt med ressursgruppen i en tidlig fase av prosjektforløpet eller søknadsskrivingen for å planlegge litteratursøket i forskningsprosessen. Dette vil kunne effektivisere og forenkle kontakten mellom ressursgruppen og viktige oppdragsgivere. 
Hvert av ressursgruppens oppdrag så langt har hatt betydelige innslag av tjenesteutvikling og kompetanseheving både innad i gruppen og blant enkelte kolleger i biblioteket. Dette har medført om lag 400 arbeidstimer våren 2017, mot 200 fakturerte timer i samme periode. Etter hvert som tjenesten blir mer rutinepreget og medlemmene blir mer erfarne i måten å arbeide på, ser vi det som sannsynlig at tjenesten vil effektiviseres og reell og fakturert tid vil nærme seg hverandre. Kompetanseheving har så langt vært essensielt for ressursgruppen, og det må også prioriteres fremover. Dette gjelder både intern og ekstern opplæring i bruk av forskjellige databaser, kompetanseheving via eksterne kursholdere innen vitenskapelig metode, arbeidsprosesser innen sekundærforskning samt metoder og kunnskapssyn innenfor ulike forskningstradisjoner.

Som nevnt er tjenesten et tillegg til de allerede eksisterende tilbudene fra biblioteket ved universitetet. Opprettelsen har ikke medført nedleggelse eller begrensning i andre tilbud. Imidlertid ble det å balansere kapasiteten opp mot målsettingen om å kunne bistå forskere som etterspør litteraturs $\varnothing \mathrm{k}$ en problemstilling som det tidlig var nødvendig å adressere. Konklusjonen ble at tilbudet måtte lanseres som en betalingstjeneste for å finansiere nødvendige personalressurser.

\section{Veien videre}

En rekke problemstillinger er aktualisert ved etableringen av tjenesten, flere av dem er knyttet til ressursbehov. Arbeidet genererer også stadig nye ideer til videreutvikling. Tjenesten har møtt et behov ved OsloMet, og ressursgruppen har fått positive tilbakemeldinger fra oppdragsgiverne. Den videre utviklingen av tilbudet vil særlig fokusere på effektivisering, metodeutvikling og kvalitetssikring. I dette avsnittet skisserer vi noen av problemstillingene og utviklingsmulighetene i det videre arbeidet.

Ressursgruppen har utarbeidet flere dokumenter for å kvalitetssikre arbeidet. Vi har en intervjuguide for $\stackrel{\circ}{a}$ avklare og konkretisere oppdragsgivernes problemstillinger før litteraturs $\varnothing$ ket igangsettes, rutinebeskrivelse for håndtering av oppdrag og forskjellige maler som forenkler arbeidsprosessene underveis $\mathrm{i}$ oppdragets faser. $\mathrm{Vi}$ ser at ytterligere konkretisering av arbeidsgangen vil være hensiktsmessig, eksempelvis en mer standardisert mal for oppsett av litteratursøkene. Vi ønsker også i større grad å legge til rette for å kunne gjenbruke elementer fra tidligere søkeoppdrag. Slike tiltak kan være en god støtte i effektiviseringen av tjenesten.

Ressursgruppen betjener som sagt et spekter av faglige miljø, og det er derfor lite trolig at tjenesten vil kunne behandle alle oppdrag likt. Det er heller ikke vårt mål. En dynamisk tilnærming er det vi mener vil være best tilpasset forskernes behov. Dette gir forskerne løpende mulighet til å utvide eller endre den opprinnelige bestillingen. Vi antar at dette vil bli enda tydeligere gjennom $\varnothing$ kende etterspørsel knyttet til samfunnsvitenskapelige problemstillinger, blant annet fordi man i langt mindre grad enn i helsefagene har tradisjon for bruk av kontrollert vokabular ved søk i databaser. Samtidig erkjenner vi at en slik arbeidsform vil kunne møte betydelige ressursmessige utfordringer. Litteraturs $\varnothing \mathrm{k}$ av det omfanget gruppen har jobbet med er tidkrevende, ikke minst fordi det fordrer tett kommunikasjon med oppdragsgiverne.

Et verktøy for å ivareta kvaliteten i de systematiske søkene er, som nevnt, fagfellevurdering. Ressursgruppen praktiserer en slik vurdering av de fleste søkene. Fagfellevurderingen er basert på den engelskspråklige PRESS-sjekklisten for systematiske søk i elektroniske databaser fra 2010 (McGowan, Sampson, \& Lefebvre, 2010; Sampson et al., 2009). Versjonen ressursgruppen bruker er oversatt og tilpasset av bibliotekarene ved Folkehelseinstituttet. Vurderingen omfatter elementer som hvorvidt søkestrategiene gjenspeiler 
oversiktens spørsmål, om relevante indekstermer er utelatt eller om det forekommer feil bruk av operatorer mellom de ulike søkekonseptene. Avhengig av prosjekttyper og omfang på oppdragene vil litteratursøkene i varierende grad gjennomgå full fagfellevurdering. Fagfellevurdering er en god måte å kvalitetssikre arbeidet, samtidig skaper dette ytterligere utfordringer med tanke på ressursbruk ettersom dette er en tidkrevende oppgave.

Det er rimelig å anta at etter hvert som tjenesten blir bedre kjent i forskningsmiljøene, vil kostnadene ved litteraturs $\emptyset$ kene kunne tas inn i søknader om eksterne midler, som fra Norges forskningsråd og EU. Så langt er erfaringene delte. Noen forskere henvender seg til oss i en tidlig fase av forskningsprosjektet, men oftest har tidsfristen for ressursgruppens bidrag vært svært knapp. Dette byr på utfordringer knyttet til disponering av personalressurser, både for ressursgruppen og biblioteket som helhet.

På et mer prinsipielt plan ser vi også et behov for å klargjøre vår rolle i samarbeidet med oppdragsgiver. Når vi involveres tett i utforming av søk vil de valg vi tar prege forskningsprosjektets endelige utforming. Dette gjelder særlig gjennom avgrensing og definering av søkebegrep. Vi ser at en større bevissthet rundt grenseoppgangen mellom forsker og bibliotekar i ivaretakelsen av den enkeltes ansvar er viktig og nødvendig. En diskusjonen rundt medforfatterskap vil antagelig bli nødvendig på sikt.

\section{Avslutning}

I denne artikkelen har vi beskrevet arbeidet med å opprette en betalingstjeneste for levering av litteraturs $\varnothing \mathrm{k}$ blant annet til systematiske oversikter. Vi har også tatt opp ulike problemstillinger knyttet til arbeidet. Hittil har ressursgruppens deltakere tilnærmet seg utviklingen av tjenesten som et prosjekt. Prosjektarbeid kan til dels ha liten forutsigbarhet og stort arbeidspress, og slike arbeidsmetoder kan være fruktbare i begrensede perioder. I vårt tilfelle har det vært nødvendig med en høy grad av kollegial forståelse og hjelpsomhet, men dette er ikke en langsiktig løsning. Når tjenesten blir en del av ordinær drift, må innsatsen og arbeidsformen avstemmes mot andre arbeidsoppgaver, og overordnede, organisatoriske spørsmål må avklares. Gitt bredden i det faglige miljøet OsloMet representerer vil det i fremtiden dukke opp adskillige spørsmål det må tas stilling til, og som også vil påvirke måten tjenesten organiseres.

Trass i utfordringer viser etterspørsel og tilbakemeldinger på opplevd relevans, kompetanse og kvalitet at en slik tjeneste for levering av litteraturs $\varnothing \mathrm{k}$ som vi har beskrevet her bør opprettholdes ved OsloMet. Arbeidet skaper en møteplass mellom bibliotekarer og forskere, og dynamikken og synergien i oppdragene gir grunnlag for stadig utvikling..

\section{Referanser}

Høgskolen i Oslo og Akershus. (2017). Strategi 2024: Ny viten - ny praksis. Retrieved from https://tilsatt.hioa.no/documents/585743/66116386/Strategi+2024_norsk2.pdf/57ad0d99 -8cf7-a0fd-75ad-6d1eda2e7127

McGowan, J., Sampson, M., \& Lefebvre, C. (2010). An evidence based checklist for the peer review of electronic search strategies (PRESS EBC). Evidence Based Library and Information Practice, 5(1), 149-154. http://dx.doi.org/10.18438/B8SG8R

Moher, D., Liberati, A., Tetzlaff, J., \& Altman, D. G. (2009). Preferred reporting items for systematic reviews and meta-analyses: The PRISMA statement. Plos Medicine, 6(7). https://doi.org/10.1371/journal.pmed.1000097 
Nasjonalt kunnskapssenter for helsetjenesten. (2015). Slik oppsummerer vi forskning: Håndbok for Nasjonalt kunnskapssenter for helsetjenesten. Retrieved from https://www.fhi.no/globalassets/kss/filer/filer/verktoy/2015_handbok_slik_oppsummere r_vi_forskning.pdf

Sampson, M., McGowan, J., Cogo, E., Grimshaw, J., Moher, D., \& Lefebvre, C. (2009). An evidence-based practice guideline for the peer review of electronic search strategies. Journal of Clinical Epidemiology, 62(9), 944-952. http://dx.doi.org/10.1016/j.jclinepi.2008.10.012

Tranfield, D., Denyer, D., \& Smart, P. (2003). Towards a methodology for developing evidence-informed management knowledge by means of systematic review. British Journal of Management, 14(3), 207-222. http://dx.doi.org/10.1111/1467-8551.00375 